Journal of History Culture and Art Research (ISSN: 2147-0626)

Tarih Kültür ve Sanat Araştırmaları Dergisi

Vol. 10, No. 1, March 2021

\title{
DOI: 10.7596/taksad.v10i1.3010
}

Citation: Gashi, A. Y. (2021). The Models of Auto-Confessional Author. Journal of History Culture and Art Research, 10(1), 98-104. doi: http://dx.doi.org/10.7596/taksad.v10i1.3010

\section{The Models of Auto-Confessional Author}

Agron Y. Gashi ${ }^{1}$

\begin{abstract}
A discussion that used a theoretical discourse as opposed to the discourse used by positivism began in the second half of the past century with the focus on the issue of the author in literature. The search for the author by the method of looking for him/her in between the lines was evident in literary theories, especially after Roland Barthes' eminent essay The Death of the Author (written in 1968). Afterwards, the issue of the author was regarded by European and Anglo-American schools as an issue to be discovered within the text either as the presence of the narrator or the author, or as an explicit presence as an auto-confessional author. Being of such an explicit nature, it is not unexpected that the auto-confessional author has oftentimes been neglected. Upon this consideration, the auto-confessional author is the object of this paper that aims to set about a theoretical and conceptual confrontation with the purpose of framing a model of the auto-confessional author and his manifestation in literature.
\end{abstract}

Keywords: Studies of Literature, Auto-confessional author, Autobiography, Semiautobiography, Objective author, Subjective author.

\footnotetext{
1 Dr.sc. Faculty of Philology, University of Prishtina, Kosovo. ORCID-ID: https://orcid.org/0000-0002-0392-

9136 E-mail: aygashi@gmail.com
} 


\section{Intoduction}

The syntagm auto-confessional author refers to the presence of the author in auto-referential texts in which he/she narrates his/her life. The auto-confessional author has been modeled quite early, ever since the classic narratives known as automajuetic ${ }^{2}$, and later in confessions as autobiography, as mea culpa, or confession of sins without a mediator, as is the case with St. Augustine's Confessions. In time, structuralist and poststructuralist theory claimed the death of the author but also his presence in the text as an implied author. Yet, even in this discussion that lasted for half a century, they could not disregard the auto-confessional author, especially in autobiographic texts.

Being part of the same field such as autobiographic literature, where the author is both subject and object, there is no possibility of truly disregarding the author. If we try to disregard him, we would only be disregarding the object of the text, or the text itself. The idea has been clarified best by Roland Barthes in his eminent essay in which he proclaimed the death of the author: Once the Author is removed, the claim to decipher a text becomes quite futile. (Barthes, 1978 : 178).

In a 1969 conference of the French Society of Philosophy, Michel Foucault asked: What is an author? The question succeeded by a year Barthes' declaration (in 1968) of the death of the author. These two texts became manifestos for many researchers everywhere as the initial take of literary modes of reading of the 70s, poststructuralism and deconstruction, but what it has actually done to theoreticians ever since has been to challenge them to bring back the author in literature as an autoconfessional author. In the texts that marked the death of the author and defined writing by defining the absence of the author, Barthes and Foucault were inspired by a form of rivalry against Lansonian literary history which they were against. They also objected to a form of literary thought as being deeply connected to its author, or literature of confession that follows the doctrine that is best illustrated in numerous literary theses: $X$ person and his oeuvre (Compagnon, 2012:203).

Before Lanson, this widely accepted doctrine used to identify with Sainte-Beuve, the first critic of the 19th century, a doctrine criticized harshly by Proust in his famous Contre Sainte-Beuve (1954), ${ }^{147}$ in which Proust criticized his biographic method, a method that not only imperiled the life of the author in literature, but also the interpretation of auto-confessional literary texts, a method that indirectly jeopardized the auto-confessional author in his autobiographic project.

\section{Theoretical confrontation}

Auto-confessional texts were even regarded as a strenuous effort to add to the positivist interpretation, while the writer of auto-confessional texts was regarded as a first hand provider of information, aware of the history and ideals of his own life. Being himself an author of such a great autobiographic project, in his theoretical text Proust attacked biographic criticism, and in praxis he represented the auto-confessional author as having a double role: a creator and a narrator. Meanwhile, Foucault gave a political dimension to an extremely Blanchotian idea: today's writing has freed itself from the dimension of expression. To Compagnon, every debate on the author is concerned with the notion of intention, i.e. on the supposed relationship between the text and its author, on the

\footnotetext{
${ }^{2}$ A dialogue whith himself, a classic concept.
} 
responsibility imposed on him in relation to the meaning of the text and the meaning of the work (Compagnon, 2012 : 204).

On such grounds, Wayne Booth, Gérard Genette, Kate Hamburger and Umberto Eco emphasized the empirical author, interviewing author, the publisher, the homodiegetic and heterodiegetic narrator, the protagonist, the narrator, the ideal reader, the empirical reader, etc.

To put it simply, theoreticians and critics cannot get rid of the author, especially the auto-confessional author, in such a short time. This is true for yet another reason: the reader constantly needs an imagined interlocutor, which he builds out of the reading act, and without which the process of reading would remain a vain abstraction. We may put biography and history aside in literary studies, we may let go of the tendency of assuming oneness in meaning, yet if we love literature, we cannot do without the figure of the author, Antoine Compagnon concluded. (Compagnon, $2012: 204$ ).

The need for such an interlocutor has been pointed out many times by the poetics of genre, at time as an autobiographic pact, at times as a phantasmatic pact (Philippe Lejeune, 1976- 42), depending on the status of the text. Thus, it is not a coincidence that the author is considered to be one of the four most important instances (Lejeune) that structures the autobiographic genre as well as self-fictional texts in which fact and fiction merge. This gives the text a signified within the law of genre (Derrida, Anderson). There is no other text in which the author is more powerful than in the literature of autobiographic origin.

Despite pro et contra discussion on the author, Barthes adds that New Criticism has done nothing but consolidate the author. This is evidently based on the great number of research on the author done by the most prestigious critics: Hirsch, Booth, Foucault, etc. These authors have separated and given a profile to the author as inquirer, creator and recreator. In each case, the model of genre, form and second instance all come to the surface as being the elements that help distinguish the model of the author. To Barthes, life never does more than imitate the book and the book itself is only a tissue of signs, an imitation that is lost, infinitely deferred (Barthes, 1999:178). Lejeune admitted that the situation of the autobiographic author is much more complex than that of the biographer. Firstly, it is not an issue of resemblance but of identity that creates a number of problems. For instance, how can it be possible to seriously consider that $a$ subject can give a clear representation of the object of his personal life? As Jean Paul Sartre arguments, each individual is free at all times of his existence to develop a project of his life and to reinterpret his past in light of that new project. This is clearly what Lejeune had in mind when he declared an evidently existentialist terminology that the ultimate expression of truth (if we regard it in terms of similarity), cannot be the being of the self of the past (if such a thing exists), but the being of the self as manifested in the present (Lejeune, 1989 : 3-30).

The most common case would be that the arrangement begin from the title, then further develop in the preface and then be confirmed throughout the text by the repetitive presentation of the name of the author. This type of author can be seen in Jean-Jacques Rousseau's Confessions (Confessions 1782, 1788). According to Lejeune, the author of an autobiography is classified as a real, social and creative person of a speech. "Placed outside and within the text in an equal amount" is the personality of the author who represents "the relation between these two aspects" (Lejeune, 1989: 171). 
The implied author has at first represented the analogy with the autobiographic author since Booth (1961) and later Genette regarded him as the real author either declared since the beginning or infiltrated within or implied at the end of the text as completing a function, as Barthes expressed (Barthes, idem, p.113).The implied author is the real author through which are produced and derived the narrative categories of the text such as form, theme, modus, and also time, voice, focalization, etc., all of which are often options and solutions of the autobiographic author.

In the type of literary works in which the author is seen not only as creator but also as the creator of the implied meaning of a certain aim, a conveyor of the idea and a personal (or collective) ideology, he thus becomes the author function and his literature becomes functionalized (Hamiti, 2013:201). The same happens to the autobiographic author who becomes one with the author function who completes a mission: the testimony, history and story of his life through a living narrative.

From the author function as having a mission to complete whether when he writes passionately or whether he is a man of a certain position in society (for a memoir), or whether as the one responsible for carrying and writing his history and that of other people (in autobiography), he is then transformed into the autobiographic author as an acting homo narrans, as an active homo reminicient or as one who ideates and practices ideologies, at which point the author becomes an authority.

In contemporary autobiographical prose there is a divergence of perspectives on the author of passion versus that of mission: the former focuses the world's attention on himself, turns the autobiographic text into a discourse of passion, whereas the latter turns the self towards the world. Is this not a path towards two models of auto-confessional authors?

\section{Two models of the author}

Where writing begins, the author enters into his own death, Barthes reminds the reader (Barthes, 2008:44). Nevertheless, he never eliminated the author from the narrative, but he simply accepted him as being part of the main categories of the text. He illustrated the removal of the narrative voice of the author quite well through the experience of personal (shamanic) narratives, narratives of ethnographic societies (auto-ethno-graphia), thus reducing his role into that of $a$ mediator who owns the narrative code. Yet, this proposition confronts it with those texts in which the narrative is conveyed without a mediator.

In order to have some harmony between such oppositions, Barthes qualifies the author as $a$ modern character, thus taking us to autobiographic poetics where the subject makes an object out of his life either overtly or under the guise of his character.

As research on autobiographic writing has proposed, there are two models of the author evident in the genres of autobiographic narrative:

\section{- $\quad$ The subjective auto-confessional author}

- The objective auto-confessional author

Their function is relative to the request made from the very beginning of the book, especially in the second model. 


\section{The subjective auto-confessional author}

The subjective author declares the modus, the type, the perspective and his identity as he reconstructs his textual agreement with the reader. It is not necessary for this type of author to be omniscient at the beginning or at the end of the text. However, the greatest part of the autobiographic space (Lejeune) is covered by his life; he is placed at the center of the text and he covers historic circumstances with his personal information. This not only happens in classical autoconfessional prose, but also in autoreferential texts we now recognize as semi-autobiography.

In European letters, Romanticism emphasized subjectivity only to delineate and continue its presence in modern and contemporary literature. In search of testimony of the self and others, autoconfessional prose even switches the narrative from the first person to the third person, thus aiming objectivity in order to resist the tyranny of subjectivity, and naturally transforming the appearance of the grammar of autobiography.

Regardless of their resistance to subjectivity, this type of author changes his mission to passion in order to narrate about the self, at times even identifying with great biblical or historical personalities.

This becomes the perfect example illustrating the idea that pronoun discourse does not indicate the aimed scale of objectivity nor of extreme subjectivity. Nevertheless, regardless of the name given to the author in auto-confessional texts, the battle on the author's objectivity might be lost, but not the war.

\section{The objective auto-confessional author}

Fan S. Noli ${ }^{3}$ evaluated auto-confessional writing as a difficult task (Noli, $2001: 10$ ), that is why third person narrative was the attempt to be free of the tyranny of subjectivity by aiming at the objective author through a distinction between the subject and the object for the purpose of achieving what he called analogon veritatis.

According to Lejeune, the autobiographic author is classified as a real, social person, as a creator of a discourse. In his view, it is the personality of the author that represents the connection between two textual spaces: inside and outside the text in an equal proportion. Such an equality, coexistence and appropriate separation inside and outside the text is the dream of every author that writes about his life. That is why the objective author belongs more to the literary referential work. In "real autobiographies" where the autobiographemes ${ }^{4}$ are built on verifiable facts, the desired objectivity is but an illusion. Nevertheless, an objective autobiographic author can oftentimes be represented by the character or the character-narrator (Aichinger, 1970: 418-438).

According to Derrida, if the auto-confessional writer who is identical to the autobiographic author will remain (only) in the request for the presentation of the self, he will thus destroy the illusion of self-reference (Bossinade, 2000: 87).

In his article Demeure, Fiction and Testimony in which he analyzes Maurice Blanchot's autobiography The Instant of my Death (Blanchot, 1994), Derrida noticed the continuity as well as the

\footnotetext{
${ }^{3}$ Albanian author of the 1920s, who lived and worked in the United States.

${ }^{4}$ A small biographic unit
} 
return of meaning in the process of spreading and sharing meaning. To Derrida, autobiography is the system of signs out of which there is no return to contextuality. For this theoretician, there is no internal being of the individual that the subject can reveal through language.

According to Derrida, the subject is dependent on others. In autobiographic prose, whether as memoir, diary, authorial notes or testament, it is only when the others are placed at the center of the text and are of equal importance as the author that the idea of a plausible and acceptable objective auto-confessional author can be taken under consideration (Derrida, 1980-77).

\section{Conclusion}

To conclude, it is evident that regardless of various theories, the auto-confessional author is inevitable due to his subjectivity which is even more apparent when it comes to typical autobiographic texts or even literary autobiographies that are now known as semi--autobiography. Thus, autoconfessional texts have reinstated the author at the center of the work as this process of being at the center automatically places other stories at the periphery.

Additionally, auto-confessional texts need to be considered here as they are now recognized as an independent genre of autobiography, especially in the new century as this type of literature has the tendency to be of a documentary nature in which fact dominates fiction and where fiction is gradually turned into a category of description rather than of narration.

Research on this theory on auto-confessional texts from today's perspective resulted in two models: the subjective auto-confessional author and the objective auto-confessional author. The subjective author covers most of the autobiographic space (Lejeune) with his life and more generally with the focus on the text itself; even when documented data exists, he equals it to personal data.

However, an objective auto-confessional author may oftentimes be represented by the character or the narrator-character, but he is constantly under pressure by his subjectivity, and that is why he has a tendency to play with facts and with the self, usually by narrating not only from the first perspective but also from the third, thus creating a distance from the subject.

Conclusively, we can now speak of the model of the author determined by the type of writing or by the genre instead of the death of the author. Specifically, we may also speak of the autoconfessional author whose presence in the text is inevitable when it comes to literary interpretation.

\section{References}

Adams, Timothy Dow (1994). Introduction: Life Writing and Light Writing, Autobiography and Photography. Modern Fiction Studies, 40, 459-491.

Aichinger, Ingrid (1970). Probleme der Autobiographie als Sprachkunstëerk. Österreich in Geschichte und Literatur, 14, 418-438.

Allet, N. \& Jenny, L. (2005). L'autobiographie, Méthodes et problems. Dpt de Français moderne, Universite de Geneve.

Bart, Rolan (1987). Aventura semiologjike. Pristina: Rilindja. 
Barthes, Roland (2008). Aventura semiologjike, (ribotim). Peja: Dukagjini.

Barthes, Roland (1975). Roland Barthes par Roland Barthes. Paris: Seuil.

Bernarda, Katušić (2014). Pismo-život, Autobiografija u novijoj hrvatskoj književnosti, Zagrbaçka slavistic skola, in (http:// www.hrvatskiplus.org/main.php).

Blanchot, Maurice (1994). L'Instant de ma mort, Fata Morgana: Montpellier.

Booth, Wayne (1961). The Rhetoric of Fiction. University of Chicago Press.

Bossinade, Johanna (2000). Poststrukturalistische Literaturtheorie. Stuttgart: Weimar (J.B. Metzler).

Campagnon, Antoine (2012). Vdekja dhe ringjallja e autorit. Pristina: Jeta e re, nr. 2.

De Chateaubriand, F. R. (1951). Mémoires d'outre-tombe, vol. I. Bibliothèque de la Pléiade. Paris: Gallimard.

Gashi, Agron Y. (2009). Autopoetika (modelet narrative autobiografike). Pristina: Faik Konica.

Gashi, Agron Y. (2017). Proza autobiografike ( poetika dhe modele). Prstina: Parnas.

Grillet, Alain Robbe (1985). Le miroir qui revient, Paris: Les Editions Minuit.

Grup Autorësh (2008). Teori dhe kritikë moderne. Pristina: Rozafa.

Kamy, Alber (2002). Njeriu i parë. Tiranë: Dritan.

Lejeune, Philippe (1977). Autobiography in the Third Person, Paris: New Literary History, 9 (1), 27-50.

Lejeune, Philippe (1996). Le pacte autobiographique (novella èdtion augmentèe), Paris: Èditions du Seuil.

Lejeune, Philippe (1975). Le pacte autobiographique, Paris: Seuil.

Marek, Heidi (2002). Fact and Fiction: The Problem of Autobiographical Writing in Lejeune Malerba. Italian Studies in Southern Africa, 15(2), 51- 65.

Marquez, Garsia Gabriel (2002). Living to tell the Tale, New York: Random House.

Mehlmann, Jeffrey (2000). A Structural Study of Autobiography: Proust, Leiris, Sartre, Lévi-Strauss, Ithaca: Cornell Univ. Press.

Noli, Fan S. 2001. Portrete dhe Skica, Tiranë: Jon.

Rousseau, Jean-Jacques (1959). Confessions, dans Oeuvres complètes, vol. I. Paris: Gallimard. 